\title{
Challenges and Responses of Uzbekistan During COVID-19
}

\author{
COVID-19 Döneminde Özbekistan'ın Karşılaştığı Güçlükler ve Uygulamaları
}

\author{
Waqas AHMED ${ }^{1}$ \\ (D) 0000-0003-2648-1001 \\ Hashim ZAMEER ${ }^{2}$ \\ (D) 0000-0002-7191-3443 \\ Timur PERKOV ${ }^{1}$ \\ (D) 0000-0002-9410-9140
}

\begin{abstract}
Like the rest of the world, the coronavirus disease 2019 (COVID-19) pandemic showed an unprecedented impact on healthcare system and economy of Uzbekistan. Due to lack of resources, stalled organizational agility and highly bureaucratic decision making, the healthcare system of Uzbekistan did not perform optimally. From the top to the bottom decision-making and path dependent strategies were adopted that were ineffective due to volatile and uncertain nature of pandemic. The whole system collapsed because of lack of beds, medical supplies and personal protective equipment (PPE) for healthcare workers. The Uzbek government needs strategic plans to keep a fine balance between the economic recovery and spending on deteriorating healthcare system. Unlike many Commonwealth of Independent States (CIS) countries Uzbekistan didn't deny the existence of COVID-19 in the country. However lack of transparency in data dissemination creates doubts of the intent and accuracy of the information. Uzbekistan would have to apply medium and long-term initiatives and foreign assistance to strengthen the macroeconomic structure and to fight with the inflation and unemployment.
\end{abstract}

Keywords: COVID-19 pandemic; health management challenges; Uzbekistan.

${ }^{1}$ Westminster International University Department of Business and Economics, Tashkent, Uzbekistan

${ }^{2}$ Nanjing University of Aeronautics and Astronautics, Department of Economics and Management, Nanjing, Jiangsu Province, China

\section{Corresponding Author Sorumlu Yazar \\ Waqas AHMED \\ wahmed@wiut.uz}

Received / Geliş Tarihi : 15.01.2021 Accepted / Kabul Tarihi : 13.03.2021 Available Online /

Çevrimiçi Yayın Tarihi : 14.03.2021

\section{öz}

Tüm dünyada olduğu gibi, koronavirüs hastalığı 2019 (coronavirus disease 2019, COVID-19) pandemisi, Özbekistan'ın sağlı sistemi ve ekonomisi üzerinde benzeri görülmemiş bir etkiye yol açmıştır. Kaynak yetersizliği, sağlık sisteminin işleyişindeki yavaşlık ve uzun bürokratik karar alma süreçleri, olumsuz etkiyi arttırmıştır. Pandeminin yapısından kaynaklanan belirsizlikler ve sürekli değişkenlikler dolayısıyla, tüm yönetsel kademelerde etkinlik sağlanamamıştır. Yatak sayısındaki yetersizlik, tıbbi malzeme kısıtı ve sağlık çalışanlarındaki yetersizlik nedeniyle tüm sağlık sistemi çökme noktasına gelmiştir. Özbek hükümetinin ekonomik iyileşme ile kötüleşen sağlık sistemi harcamaları arasında iyi bir denge sağlamak için oldukça kapsamlı stratejik planlara ihtiyacı vardır. Pek çok Bağımsız Devletler Topluluğu (BDT) ülkesinden farklı olarak Özbekistan, COVID-19 pandemisinin ülkede etkili olduğu gerçeğini inkar etmemiştir. Ancak veri paylaşımındaki yetersiz şeffaflık, bilginin doğruluğu hakkında şüphelerin artmasına yol açmaktadır. Zaten uzun yıllardır ekonomik ve sosyal hayatta önemli sorunlarla boğuşan Özbekistan'ın, pandeminin de kötüleştirdiği sağlık sektörü başta olmak üzere, enflasyon ve işsizlik gibi sorunlarla mücadele etmek ve makroekonomik performansını güçlendirmek için orta ve uzun vadeli girişimlere ve yabancı yatırımlar ile dış yardımlara ihtiyaç duyacak gibi görünmektedir.

Anahtar kelimeler: COVID-19 pandemisi; sağlık yönetimi sorunları; Özbekistan. 


\section{INTRODUCTION}

The first signals of upcoming coronavirus disease 2019 (COVID-19) caused by severe acute respiratory syndrome coronavirus 2 (SARS-CoV-2) infection from Wuhan city of China have been received worldwide at the end of December 2020 (1). The world-leading news agencies started monitoring China's situation and in January reported that Wuhan City faced a lockdown and its citizens were required to stay at home to stop the spread of the coronavirus (2) it is reviewed as the most effective measure (3). However, the preventive measures taken by People's Republic of China (PRC's) official authorities did not stop the virus from getting out of the country of origin and reaching 72 countries later in total. Strongly pressuring a global healthcare system, COVID-19 has been considered as a threat for the population and the pandemic has been declared by the World Health Organization (4). The Central Asian region remained uninfected for an extended period in early 2020 compared to other countries. Some researchers believe that previous successful experience in prompt and adequate arrangements for preventing the severe acute respiratory syndrome (SARS) epidemic in 2003 was a ground for this phenomenon in 2020. However, firmly believing in the effectiveness of measures did not let local medical authorities manage risks accordingly (1). Simultaneously, unlike Tajikistan and Turkmenistan, Uzbekistan did not tempt to hide numbers of infected people or deny the COVID-19 existence in the country (5).

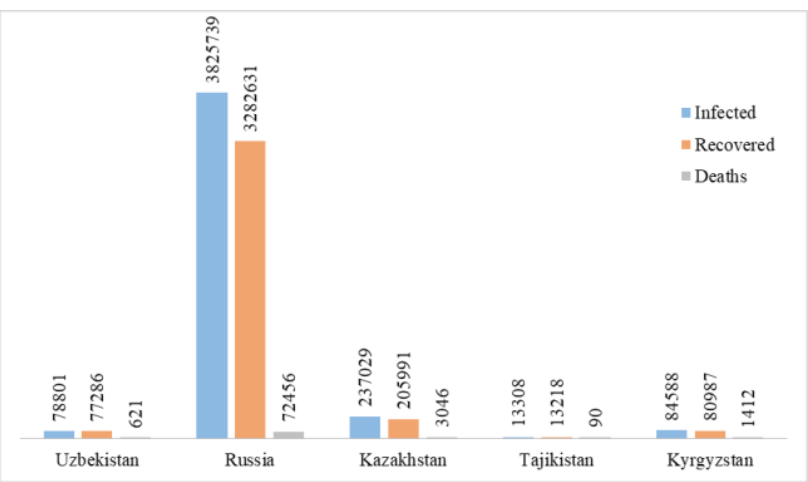

Figure 1. COVID-19 in CIS countries (6)

\section{Uzbek Government's Response to COVID-19}

The Uzbek mass media reported on the first infection case at 6 AM on Sunday, 15 March 2020. When one of the passengers arrived from Paris, France, two days earlier, was hospitalized with a high temperature and other COVID-19 symptoms such as cough and sore throat. Bakhrom Almatov - the head of Sanitary-Epidemiological Peace and Public Health Service, informed that all passengers of that flight and any other people who could potentially have contact with the infected person, all have been identified and were taken under the constant monitoring same day (7). Uzbekistan and Kazakhstan and Kyrgyzstan tried to be proactive in the implementation of a combination of measures aimed to stop or at least slow down the spread of the infection (5). As a result, Abdulla Aripov (the Prime Minister of the Republic of Uzbekistan) headed the Special Republican Commission to prevent the import and spread of COVID-19 has announced during the briefing that took place on 15 March 2020. Thus, from the 16 March 2020, Uzbekistan terminated road and air transportation and cross-border traffic with foreign countries while the local railways' company (JSC "O'zbekiston Temir Yo'llari") was given three days to prepare for the service termination. The 14-days quarantine requirement was applied following the announcement of the charter flight program for the Uzbek expatriates. Other measures included the cancellation of the public celebration of Navruz (local public holiday scheduled on $21 \mathrm{March}$ ) and termination of local cinema operations. Students from local medicine universities were attracted to conduct a preventive consultancy with the local population in regions. Moreover, the prime minister claimed that all Uzbekistan regions are supplied with COVID-19 testing and protection systems. Hence, he requested to increase the production of facemasks to prevent its shortage in local pharmacy shops (8).

From the same day, to prevent the spread of the infection and ensure the sanitary and epidemiological situation across pre-school, school and university levels, spring holidays were announced (9). Following the example of the PRC (10), Uzbekistan announced the building of a 10k places hospital for COVID-19 patients (11) alongside with organizing a special camp "O'rtasaroy" for incoming citizens from abroad for 14-days quarantine period. Moreover, local student accommodations were turned into quarantine centers for people within Uzbekistan (12). Quarantine measures were introduced by the government from 06 April until 27 April 2020 aimed to slow down the spread of the infection. Considering the spread and severity, Uzbekistan's regions were divided into three (green, yellow and red) zones (13).

\section{Business Continuity Planning and Civic Response}

Within the first few days after a lockdown announcement, Uzbeks started stocking up on essential goods. Local retailers HAVAS, Korzinka.uz and Macro reported that such products as buckwheat, rice, wheat flour, seed oil and hygiene products demonstrated a significant increase in demand (14). However, the active measures taken by the government on time let retailers maintain an adequate supply. To ensure that people wear facemasks, the authorities introduced a system of fines (first time warning, then 223,000 soms are to be paid on second warning and 669,000 soms on third one) effective from 6 AM 25 March 2020 (15). Keeping in mind the average income level of $2.5 \mathrm{mln}$ soms for that period (16), the fine proposed was considered quite punitive for the local citizens. After that period, the measures were reconsidered, and areas classified as "green" zones received more freedom.

Nevertheless, the hygiene requirements were necessary for following when entering shops and public places. However, the state police department reported an increased number of cases when people did not follow these regulations. As a result, in June, the number of infection and death cases has tripled. E.g., If in May 51 cases of the disease were registered daily in Uzbekistan, then in June there were already 163. According to the Ministry of Internal Affairs' official statistics, 71028 cases of the regulation breach have been identified, and the government raised $\$ 4.5 \mathrm{mln}$ of fines (17). Uzbekistan's 
President declared the return back to the strict isolation measures starting from the 10 June until 01 August that was prolonged until 15 August 2020 later (18).

Such strict measures put extra strain on the vulnerable and people with psychological issues. On 22 June 2020, a suicide case took place at "O'rtasaroy" camp when a man has been found hanged inside a container. The investigation has shown that patient hanged himself due to psychological problems (19). Prolonged quarantine periods led to the financial stress for already dwindling financial position of general public. At the time, when the US or Hong-Kong paid approx. \$1200 to every citizen monthly (since many of them were put on remote work or lost their jobs) nothing similar was planned in Uzbekistan. The local authorities identified around 120000 most vulnerable families during 20-days quarantine and allocated them with free foods or financial aids (20). However, such initiatives were not sufficient and increased health vulnerability of financially strained population.

\section{Challenges}

Central Asia was once quite closed and isolated with global networks. Uzbekistan improved its position in terms of openness and foreign exposure since 2016. The lucky escape from the SARS outbreak in 2003 lead authorities a wrong assumption of having appropriate system in place in case of pandemics (1). The biggest challenge that Uzbekistan faced was lack of preparedness in terms of healthcare responsiveness and agility. The top to bottom decision-making and path dependent strategies were adopted that were ineffective due to volatile and uncertain nature of pandemic. The whole system collapsed because of lack of beds, medical supplies and personal protective equipment (PPE) for healthcare workers (21). Many hospitals refused to entertain anyone with symptoms similar to COVID-19 and fever even though the patients were facing other diseases. Emergency services did not answer calls or send ambulance for many patients due to non-availability of proper services (5). During first wave, the preparation very much focused cities (1) whereas large population living in rural or remate were largely ignored that lead to an increase in number of deaths in Karakalpakistan and Jizzakh regions of Uzbekistan (6). Ignoring such large number of population left rest of healthy population at the risk of exposure and reemergence of the disease. Another dynamic of flattening the curve strategy was creating awareness and limiting movement of population. Considering the fragile nature of industry and small business, it was very hard for Uzbek government to prolong hard lockdown in order to provide livelihood to people. Enforcement of lockdown and facemasks was not effective despite heavy fines due to religious and cultural values and collective culture.

The COVID-19 pandemic has demonstrated the vulnerability of not only ordinary people but also entrepreneurs. Uzbekistan services sector was very badly affected due to strict lockdowns and closure of the business centers. Most businesses tried to cut their overhead expenditure $b$ laying off or stop paying their workers. Uzbekistan was heavily relying on foreign remittances of expatriates living in Russia, South Korea, UAE and Turkey that were laid off and sent back home, adding more strain to unemployment. Similar to the world's declining trends (22) while Food and Beverages (F\&B) companies remained partially open due to Uzbekistan's food delivery services, fitness centers and tourism agencies reported their customer database decreased up to $60 \%$. The government's program aimed to support the F\&B sector included the tax exemption until 2021. However, the same approach was not adequate for tourism agencies since no revenues were demonstrated. Learning centers managed the implementation of online teaching approach but reported the internet connectivity issues across the country (especially in suburban areas). Another problem raised by local mass media was the tendency to hide the real statistics of infected cases in the third quarter of 2020 by the Governmental Statistics Centre (23). Official stats published by the Uzbek Ministry of Health could have been inaccurate or even false. The Ministry stopped providing detailed statistics by region. Moreover, as mentioned, they no more indicate the gender, age, initials of names and place of residence (treatment) of deceased patients with COVID-19 (23).

\section{CONCLUSION and FUTURE PROSPECTS}

Uzbekistan response to COVID-19 provides interesting insights about governance of healthcare system. It has been learned that agile and inclusive decision-making could be more effective. Uzbekistan financial resources would require careful consideration about investment in economic recovery while improving healthcare as immediate priority. According to local F\&B experts' forecast, the end of the pandemic will not bring the eventindustry back to the pre-pandemic levels. Instead, it will be a roll-back to indicators of 2015-2016 (22). Therefore, companies are getting ready for a long-term recovery period. This can be proved from the graph below (Figure 2) indicating the initial forecast of Uzbekistan's gross domestic product (GDP) (optimistic) as per October 2019 and corrected forecast (real) as per May 2020 (24).

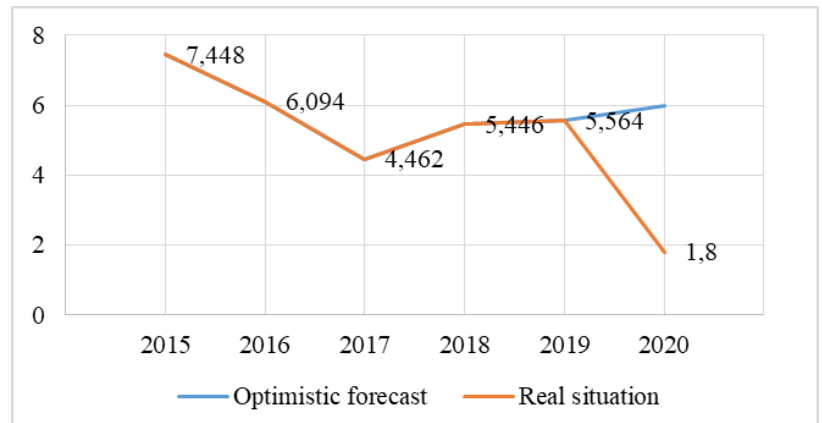

Figure 2. Uzbekistan's GDP

Recently Uzbekistan demonstrated the interest in vaccination of its population. As a result, three types of vaccine were recently ordered or already imported:

- 6000 dozes (out of which 3000 are placebo) of Chinese "Anhui Zhifei Longcom Biopharmaceutical" - 100 dozes of Russian "Sputnik V" for certification and laboratory testing

- 100000 dozes of American-German "Pfizer/BioNtech" via COVAX program

Uzbekistan plans to continue testing the vaccines and looks forward to localizing one of the above vaccine (25). 
Vaccination is expected to start at spring, and by the beginning of June $60 \%$ of the population will be vaccinated according to the Ministry of innovative development of the Republic of Uzbekistan (26). The government of Uzbekistan is applying certain medium- and long-term policy to uplift and revive dwindling industries by structural reforms. Domestic bailout plan for economic support is more likely to increase inflation and Uzbekistan must consider foreign assistance to ease of the situation. Keeping in mind the highly collective society awareness and education should be provided by the heads of communities and Imams and inclusive policy and revolving plans should be encouraged instead of quasi authoritarian plans.

Ethics Committee Approval: Since our study was a review, ethics committee approval was not required.

Conflict of Interest: None declared by the authors.

Financial Disclosure: None declared by the authors.

Acknowledgements: None declared by the authors.

Author Contributions: Idea/Concept: HZ; Design: WA; Data Collection/Processing: WA; Analysis/Interpretation: WA; Literature Review: TP; Drafting/Writing: TP; Critical Review: HZ.

\section{REFERENCES}

1. Gleason G, Baizakova K. COVID-19 in the Central Asian Region: National responses and regional implications. Connections QJ. 2020;19(2):101-14.

2. gazeta.uz [Internet]. Gazeta.uz. Wuhan residents banned from leaving city due to coronavirus. [Cited: 2021 Feb 2]. Available from: https://www.gazeta.uz/ru /2020/01/23/coronavirus/.

3. Bayesheva D, Boranbayeva R, Turdalina B, Fakhradiyev I, Saliev T, Tanabayeva S, et al. COVID19 in the paediatric population of Kazakhstan. Paediatr Int Child Health. 2020; [Epub ahead of print]. doi: 10.1080/20469047.2020.1857101.

4. Li H, Liu SM, Yu XH, Tang SL, Tang CK. Coronavirus disease 2019 (COVID-19): current status and future perspectives. Int $\mathrm{J}$ Antimicrob Agents. 2020;55(5):105951.

5. Balakrishnan VS. COVID-19 response in Central Asia. Lancet Microbe. 2020;1(7):e281.

6. gazeta.uz [Internet]. Gazeta.uz. Coronavirus COVID19: statistics for Uzbekistan and the world. [Cited: 2021 Feb 3]. Available from: https://www.gazeta.uz/ru /coronavirus-stat/.

7. gazeta.uz [Internet]. Gazeta.uz. First case of coronavirus registered in Uzbekistan. [Cited: 2021 Feb 2]. Available from: https://www.gazeta.uz/ru/2020/03/15/covid/.

8. gazeta.uz [Internet]. Gazeta.uz. What measures have been taken in Uzbekistan against coronavirus. The main thing. [Cited: 2021 Feb 3]. Available from: https://www.gazeta.uz/ru/2020/03/15/measures/.

9. uzedu.uz [Internet]. Ministry of Public Education of the Republic of Uzbekistan. Holidays are announced in all schools of Uzbekistan. [Cited: 2021 Feb 3]. Available from: https://www.uzedu.uz/ru/16-martdantatil-elon-qilinadi.
10. apnews.com [Internet]. McDonald J. China builds hospital in 5 days after surge in virus cases. [Cited: 2021 Feb 3]. Available from: https://apnews.com/ article/beijing-health-coronavirus-pandemic-wuhanchina-c555525ecdaea032b6d1bc1ec2894513.

11. curenttime.tv [Internet]. Current Time. A hospital for coronavirus infected with 10 thousand beds is being built in Uzbekistan. [Cited: 2021 Feb 3]. Available from: https://www.currenttime.tv/a/uzbekistancoronavirus-novaya-bolnitsa/30574327.html.

12. podrobno.uz [Internet]. Uzbekistan News. In Uzbekistan, hostels of universities and colleges will be converted into quarantine centers. Quarantine zone in Urtasaray will accept only arrivals from abroad. [Cited: 2021 Feb 3]. Available from: https://podrobno.uz/cat /obchestvo/v-uzbekistane-obshchezhitiya-vuzov-ikolledzhey-pereoboruduyut-v-karantinnye-tsentrykarantinnaya-zo/?sphrase_id=1151110.

13. gazeta.uz [Internet]. Gazeta.uz. In Tashkent - "yellow” level of quarantine (all regions). [Cited: $2021 \mathrm{Feb} 3]$. Available from: https://www.gazeta.uz/ru/2020/05/06/ regions/.

14. gazeta.uz [Internet]. Gazeta.uz. What Uzbeks were stocking up on because of coronavirus. [Cited: 2021 Feb 3]. Available from: https://www.gazeta.uz/ru/ 2020/03/28/markets/.

15. podrobno.uz [Internet]. Uzbekistan News. Mandatory wearing of a mask in public places is introduced in Uzbekistan. Fines are stipulated for her absence. [Cited: 2021 Feb 3]. Available from: https://podrobno.uz/cat/ obchestvo/v-uzbekistane-vvoditsya-obyazatelnoenoshenie-maski-v-obshchestvennykh-mestakh-za-eeotsutstvie-pred/?yrwinfo $=1585037718745201$ 343384120385410293993406-sas3-5909.

16. kun.uz [Internet]. Kun.uz. Average monthly salary in Uzbekistan announced. [Cited: $2021 \mathrm{Feb} 3$ ]. Available from: https://kun.uz/en/news/2020/04/25/averagemonthly-salary-in-uzbekistan-announced.

17. podrobno.uz [Internet]. Uzbekistan News. During the quarantine in Uzbekistan, fines of more than \$4.5 million were issued, [Cited: 2021 Feb 3]. Available from: https://podrobno.uz/cat/obchestvo/za-vremyakarantina-v-uzbekistane-vypisali-shtrafy-bolee-chemna-4-5-milliona-dollarov-sanepidemnadz/.

18. ritmeurasia.org [Internet]. Stolpovsky O. COVID-19 in Uzbekistan. Chronicle of events in a pandemic. [Cited: 2021 Feb 3]. Available from: https://www.ritmeurasia. org/news--2020-08-12--covid-19-v-uzbekistane.hronika-sobytij-v-usloviah-pandemii-50378.

19. kabar.kg [Internet]. Kabar. Man commits suicide in Uzbekistan in quarantine center. [Cited: 2021 Feb 3]. Available from: http://en.kabar.kg/news/mancommits-suicide-in-uzbekistan-in-quarantine-center/.

20. review.uz [Internet]. Review.uz. How is Uzbekistan fighting the pandemic? [Cited: 2021 Feb 3]. Available from: https://review.uz/post/kak-uzbekistan-boretsyas-pandemiey.

21. Nicola M, Alsafi Z, Sohrabi C, Kerwan A, Al-Jabir A, Iosifidis $\mathrm{C}$, et al. The socio-economic implications of the coronavirus pandemic (COVID-19): A Review. Int J Surg. 2020;78:185-93.

22. podrobno.uz [Internet]. Uzbekistan News. "In five months we went into a deep minus." How business is coping with the consequences of the coronavirus 
epidemic. [Cited: 2021 Feb 3]. Available from: https://podrobno.uz/cat/obchestvo/za-pyat-mesyatsevmy-ushli-v-glubokiy-minus-kak-biznes-

spravlyaetsya-s-posledstviyami-epidemii-koron/.

23. gazeta.uz [Internet]. Gazeta.uz. How True Are Official COVID-19 Statistics? [Cited: 2021 Feb 3]. Available from: https://www.gazeta.uz/ru/2020/09/23/covid-stat/.

24. worldbank.org [Internet]. The World Bank. GDP growth (annual \%) - Uzbekistan. [Cited: 2021 Feb 3]. Available from: https://data.worldbank.org/indicator/ NY.GDP.MKTP.KD.ZG?locations=UZ.
25. sputniknews.ru [Internet]. Sputnik. Vaccination against COVID-19 in Uzbekistan - what you need to know. [Cited: 2021 Feb 3]. Available from: https://uz.sputniknews.ru/infographics/20210128/158 86502/Vaktsinatsiya-ot-COVID-19-v-Uzbekistane-chto-nado-znat.html.

26. sputniknews.ru [Internet]. Sputnik. How is vaccination carried out in Uzbekistan - an expert's answer. [Cited: $2021 \mathrm{Feb} 3$ ]. Available from: https://uz.sputniknews.ru society/20210112/15771110/Kak-osuschestvlyaetsyavaktsinatsiya-v-Uzbekistane---otvet-eksperta.html. 